\title{
Windrow grazing and baled-hay feeding strategies for win- tering calves
}

\author{
JERRY D. VOLESKY, DON C. ADAMS, AND RICHARD T. CLARK
}

Authors are repsectively Associate Professor, Agron. and Hort. Dept., Professor Anim. Science Dept., and Professor Agr. Econ. Dept., Univ. of NebraskaLincoln, West Central Res. and Ext. Center, 461 West University Drive, North Platte, Nebr. 69101.

\section{Abstract}

Management practices that lower livestock production costs are of interest to ranch enterprises. Windrow or swath grazing is a strategy where livestock directly graze windrow-stored forage, generally during a time when packaged hay or some other feed is provided. The objectives of this study were: 1) to quantify calf performance and forage intake and waste under windrow grazing (windrow) and bale-fed (bale) management strategies; 2) to quantify hay quality changes as affected by storage method and time; 3) to determine the effects of windrow coverage on subsequent meadow herbage yield and composition; and 4) to compare costs and returns associated with windrow and bale strategies. The forage source was wet meadow dominated by cool-season perennial species with alternating windrows baled and the remaining windrows left in place for direct grazing. Weaned steer calves were fed baled hay or grazed windrows during a November-January period each of 2 years. Windrow grazing calf gains were greater $(P<0.05)$ than bale-fed during the first year of the study but gains were similar during the second year. Greater weight gain for windrow calves during the first year was likely due to the presence of high quality regrowth that occurred after hay harvest. Diet samples collected from fistulated windrow animals in December contained $14.6 \%$ crude protein (CP) compared to $10.4 \%$ for hand-collected samples of windrows $(P<$ 0.05). Crude protein content of windrow- and baled-stored forage was similar $(10.6 \%, P>0.05)$ during all sampling months (September-February). Crude protein content of standing (stockpiled) forage declined to $5.7 \%$ by February. Acid detergent fiber (ADF) and neutral detergent fiber (NDF) were similar between windrow and standing storage treatments during all months and higher than bales from November through February. Herbage yield was $20 \%$ less in the area directly covered by windrows the previous fall and winter compared to the control $(P<0.05)$. However, only about $9 \%$ of the total area of a pasture is affected by windrow-coverage when $1-\mathrm{m}$ wide windrows are created $11 \mathrm{~m}$ apart, resulting in an overall herbage yield reduction of $1.5 \%$. Total forage production costs for the bale-fed strategy were about $\$ 63 \mathrm{ha}^{-1}(37 \%)$ higher than windrow grazing due to baling and bale moving costs. Feed costs averaged $\$ 0.16$ head $^{-1}$ day $^{-1}$ for windrow and $\$ 0.30$ head $^{-1}$ day $^{-1}$ for the bale strategy. When production data were applied to market prices for the previous 7 years, the mean net return ha. ${ }^{-1}$ for windrow

Published with the approval of the director of the Univ. of Nebraska-Lincoln, Inst. of Agr. and Natur. Resources, Agr. Res. Div. as Journal Ser. no. 13151

This research was funded by the Arthur W. Sampson Range and Pasture Endowment. The authors thank Troy M. Walz, Timothy L. Griffin, and Russell E. Sandberg of the Univ. of Nebraska-Lincoln for technical assistance.

Manuscript accepted 15 Feb. 01.

\section{Resumen}

Las practicas de manejo que disminuyen lo costos de producción del ganado son de interes para muchas empresas ganaderas. El apacentamiento de heno cortado y dejado en hileras en el campo es una estrategia donde el ganado apacienta directamente el forraje de estas hileras, generalmente cuando el heno empacado o alguno otro alimento es suministrado. Los objetivos de este estudio fueron: 1) cuantificar el comportamiento productivo del becerro y el consumo de forraje y desperdicio en el apacentamiento de forraje almacenado en hileras y empacado, 2) cuantificar los cambios de calidad del heno debido al método y tiempo de almacenamiento, 3) determinar los efectos de la cobertura de las hileras del heno en el rendimiento de forraje y composición subsecuentes de la pradera y 4) Comparar los costos y la tasa de retorno asociados con las estrategias de almacenamiento en hileras y empacado. La fuente de forraje fue una pradera humeda dominada por zacates perennes de estación fría, las hileras de forraje se manejaron alternadamente empacando unas hileras y las otras dejadas en el terreno para apacentamiento directo. Durante 2 años, en el periodo de Noviembre a Enero, becerros machos destetados se alimentaron con heno empacado o apacentaron las hileras de forraje sin empacar. Durante el primer año la ganancia de los becerros apacentando el heno en hileras fueron mayores $(P<\mathbf{0 . 0 5})$ que la de los alimentados con heno empacado, sin embargo, las ganancias del segundo año fueron similares. La mayor ganacia obtenida en el primer año por los becerros apacentando heno en hileras proablemenre se debio a la presencia del rebrote de alta calidad que ocurre después de la cosecha del heno. Las muestas de la dieta colectadas de animales fistulados apacentando en heno en hileras contenia $14.6 \%$ de proteína cruda, comparado con el $\mathbf{1 0 . 4 \%}$ de las muestras colectadas manualmente de las hileras $(P<0.05)$. Durante todos los meses de muestreo (Septiembre - Febrero) el contenido de proteína cruda fue similar para el heno almacenado en hileras y el empacado $(10.6 \%, P>0.05)$ El contenido de proteina cruda del forraje almacenado en pie disminuyó a $5.7 \%$ en Febrero. La fibra ácido detergente (FAD) y la fibra neutro detergente (FND) fueron similares entre el forraje almacenado en hileras y el que se almaceno en pie durante todos los meses del estudio, y de Noviembre a Febrero fueron mayores que los del heno empacado. EI rendimiento del área directamente cubierta por las hileras de heno fue $20 \%$ menos comparada con el control en el otoño e invierno previos $(P<0.05)$. Sin embargo, aproximadamente solo el 9\% del area total de la pradera es afectada por la cobertura del heno en hileras, esto cuando el 'ancho de las hileras es de $1 \mathbf{~ m}$ y la separación entre ellas de $\mathbf{1 1} \mathrm{m}$, resultando en una reducción general del rendimiento de forraje de $1.5 \%$. Los costos totales de producción del forraje para la estrategia de alimentación con forraje empacado fueron aproximadamente $\$ 63$ dolares $\mathrm{ha}^{-1}$ 
más altos que los costos del apacentamiento de heno almacenado en hileras, esto debido a los costos de empaque y movimiento de las pacas. Los costos de alimentación promediaron $\$ 0.16$ cabeza $^{-1}$ día $^{-1}$ para el heno en hileras y de $\$ \mathbf{\$ 0 . 3 0}$ cabeza $^{-1}$ día $^{-1}$ para el heno empacado. Cuando los datos de producción fueron aplicados a los precios de mercado de los 7 años previos, el retorno neto medio ha $^{-1}$ del heno en hileras excedio al retorno neto del heno empacado por aproximadamente \$ 93 dolares y el retorno neto para una estrategia que vendió directamente el heno por \$ 174 dólares.

exceeded the net return for the bale strategy by about $\$ 93$ and the net return for a strategy that directly sold the hay by $\$ 174$.

Key Words: diet quality, economics, forage intake, forage quality, forage waste, meadow hay, weight gain

Lowering production costs using efficient management practices is of interest to ranch enterprises. Using strategies that extend the normal grazing season for range livestock enterprises is one approach that can reduce costs. Adams et al. (1994) reported that grazing Sandhills wet meadows with cows with calves during May rather than feeding hay increased calf weaning weight and reduced feeding costs. Other strategies include use of complementary grazing of seeded forages (Lodge 1970, Nichols and Clanton 1987, Vallentine 1990), grazing of stockpiled forages (Ocumpaugh and Matches 1977), or any approach that places greater reliance on the grazing animal rather than machines for harvesting forages (D'Souza et al. 1990).

Another strategy to potentially lower harvest and feeding costs is the direct grazing of windrows or swaths in lieu of baling. The objective of this strategy is to produce windrow-stored forage that will match the nutrient requirements of a certain class of livestock. McCaughey (1997) reported that additional benefits include reduced machinery use for handling manure and that livestock are provided with exercise and a clean environment. Cows grazing windrowed oats maintained body condition and back-fat similar to cows fed a typical winter ration of haylage, straw, and barley grain (AAFRD 1998). Turner and Angell (1987) reported similar winter crude protein content of mountain meadow forage that was either baled or bunch-raked. Cows grazing the bunch-raked forage also gained $10 \mathrm{~kg}$ more body weight than those fed baled hay.
We initiated a 2-year study in 1997 to evaluate windrow grazing of meadow forage with weaned calves as an alternative to the conventional feeding of baled hay. Our approach was unique in that we harvested regrowth meadow hay in an attempt to provide a forage that would meet the nutrient requirements of a weaned calf. The objectives were: 1) to quantify calf performance, feed intake, and waste under windrow grazing and hay feeding management strategies; 2) to quantify hay quality changes as affected by storage method and time; 3 ) to determine the effects of windrow coverage on subsequent wet meadow herbage yield and composition; and 4) to compare costs and returns associated with windrow grazing and hay feeding strategies.

\section{Materials and Methods}

\section{Study Area and Pasture Sites}

The study was conducted from 1997 to 1999 at the University of Nebraska, Gudmundsen Sandhills Laboratory (GSL), $11 \mathrm{~km}$ northeast of Whitman, Nebr. (42 ${ }^{\circ}$ $04^{\prime} \mathrm{N} 101^{\circ} 26^{\prime} \mathrm{W}$, elevation $=1075 \mathrm{~m}$ ). Mean annual precipitation at the site is 460 mm with about $75 \%$ occurring from April through September. The average January temperature is $-6.2^{\circ} \mathrm{C}$ and the average July temperature is $22.3^{\circ} \mathrm{C}$.

Experimental pastures were established on a subirrigated range site of a wet meadow that had primarily been used for hay production. Soils of the study pastures are Elsmere loamy fine sands (sandy, mixed, mesic Aquic Haplustolls) and GannettLoup fine sandy loam (coarse loamy, mixed, mesic Typic Haplaquoll) derived from an eolian sand parent material. Vegetation of the study pastures was dominated by cool-season species including smooth bromegrass (Bromus inermis Leyss.), redtop bent (Agrostis stolonifera L.), timothy (Phleum pratense L.), slender wheatgrass [Agropyron trachycaulum (Link) Malte], Kentucky bluegrass (Poa pratensis L.), and bluejoint reedgrass [Calamagrostis canadensis (Michx.) Beauv.]. Several species of sedges (Carex spp. and Cyperus spp.), rushes (Scirpus spp.), and spikerushes (Eleocharis spp.) were present at the site with slough sedge (Carex atherodes Spreng.) and Nebraska sedge (C. nebraskensis Dewey) being particularly abundant. Prairie cordgrass (Spartina pectinata Link) was the major warm-season species and minor amounts of big bluestem (Andropogon gerardii Vitman) and switchgrass (Panicum virga- tum L.) were present. Red clover (Trifolium pratense L.), alsike clover (Trifolium hybridum L.) and white clover (T. repens L.) were minor components of the vegetation.

Three rectangular, 3.25-ha pastures were fenced during May 1997. Pastures were located on the edge of the meadow basin and extended about halfway to the center of the basin. Degree of soil wetness, duration of flooding, and proximity to water table increased down slope.

\section{Grazing, Haying, and Livestock Management}

Each of the 3 pastures were grazed by mature cows with calves at 96 animalunit-days (AUD) ha ${ }^{-1}$ during the last 2 weeks of May in 1997 and 1998. This stocking rate resulted in heavy utilization with nearly all of the available forage being removed. After grazing, pastures were fertilized at a rate of $65 \mathrm{~kg} \mathrm{~N}, 22 \mathrm{~kg}$ $\mathrm{P}$, and $22 \mathrm{~kg} \mathrm{~S} \mathrm{ha}^{-1}$, and allowed to grow the remainder of the summer. A sickle-bar mower was used to cut the forage in each pasture on 1 September 1997. Inclement weather delayed hay harvest until 22 September in 1998. Cut forage was raked into windrows that were approximately 1 $\mathrm{m}$ in width and $11 \mathrm{~m}$ apart. Alternate windrows were then baled (450 $\mathrm{kg}$ round), and bales removed. Remaining windrows were left in place. Within a pasture, windrow location was different each year to avoid covering the same area with a windrow 2 successive years.

The grazing and feeding trial began in mid-November and continued through January of each year. Forty-eight steer calves were randomly allocated into 3 replicate groups ( 8 head each) for the windrow grazing (windrow) treatment and 3 replicate groups for the bale-fed (bale) treatment. Calves were 1/4 Hereford, 1/4 Angus, 1/4 Simmental, and 1/4 Gelbviegh and had an initial weight was $203 \mathrm{~kg}$. They were approximately 8 months of age and had been weaned in October. Calves did not receive implants prior to the trials. In each windrow pasture, temporary electric fencing was used to initially allocate about 0.5 ha to the calves. This size of area contained about 200 linear $\mathrm{m}$ of windrow and $800 \mathrm{~kg}$ total windrowed forage. Every 10 to 14 days, the temporary fence was advanced to allow access to an additional 0.5 ha of ungrazed windrow area. A back-fence was not used so calves had the opportunity to utilize previously grazed areas, but were observed to graze in the windrow area where they had most recently been given access. Bale-fed 
calves were kept in dry-lot pens and fed hay packaged from the alternate windrows in the corresponding pastures. Each pen of 8 calves had free-choice access to a single bale placed in a circular, ring-type feeder. A new bale was added when remaining hay was no longer accessible from the feeder.

Both windrow and bale calves received supplemental salt and mineral on a freechoice basis. All calves were weighed at the beginning and end of the trial period. Intermediate weights also were taken during the first week of December and January of each year. Weighing took place after a 14-hour overnight fast from food and water.

Each year in February following the grazing period by calves, 145 head of mature, dry cows were used to remove additional forage from the windrow pastures. This single herd sequentially grazed each entire windrow replicate pasture for 2 days (107 AUD ha ${ }^{-1}$ ) in the first year of the trial and for 3 days (161 AUD ha ${ }^{-1}$ ) in the second year.

\section{Hay Yield and Herbage Standing Crop}

Hay yield in fertilized and control subplots was determined by hand-harvesting methods in the week before the mechanical hay harvest of each whole pasture. Three control sub-plots were established in each pasture by placing a $4 \times 6 \mathrm{~m}$ tarp over the ground before the broadcast application of fertilizer. After the fertilizer application, the tarps were removed and sub-plot locations marked. Fertilized subplots were located adjacent to the control sub-plots. A hand-operated sickle-bar mower was used to cut three, $1 \times 4.9 \mathrm{~m}$ strips in each control and fertilizer subplot. The mower was set to leave an approximate $6-\mathrm{cm}$ stubble height. Cut forage was gathered and weighed. Sub-samples were collected from each strip and oven-dried at $60^{\circ} \mathrm{C}$ to a constant weight for dry matter determination.

Herbage standing crop before (midNovember) and after (late-January) the winter calf grazing period was determined by hand-clipping 20 , randomly-located $0.25-\mathrm{m}^{2}$ quadrats in each windrow pasture. All herbage within a quadrat was clipped to ground level, bagged, and later ovendried at $60^{\circ} \mathrm{C}$ to a constant weight. Because clipping was at ground level, this herbage included all growth that had occurred after the 1 September 1997 or 22 September 1998 hay harvest as well as any residual plant material that was below the 6-cm mowing height.

\section{Forage Intake}

Fecal output for estimation of forage intake was determined with 18 calves during December 1997 and 1998. Three calves from each windrow or bale replication were sampled. Each calf on the intake trial was orally dosed with an intraruminal continuous chromium $(\mathrm{Cr})$-releasing device $^{1} 5$ days before a 6-day fecal collection period (Adams et al. 1991). Calves on the intake trial were observed each morning until they defecated and 300 to $500 \mathrm{~g}$ of feces collected. Forage intake was estimated by dividing fecal output by the indigestibility of the forage diet (Kartchner 1980).

Concurrent with the fecal collections for the windrow and bale calves, total fecal collections were made on 8 steer calves that were similar in weight and age to those under the windrow and bale treatments. These calves were dosed with the same intraruminal continuous $\mathrm{Cr}$ releasing device and fitted with fecal bags for total fecal collection to obtain a correction factor for total fecal output (Adams et al. 1991, Hollingsworth et al. 1995). Four of the calves were individually fed baled hay and 4 were individually fed hay collected from windrows. Bale and windrow forages were mixed collections from each of the 3 replications. Feces collected in the bag were weighed, mixed, and sub-sampled (300 to $500 \mathrm{~g}$ ) daily during the 6-day collection period. Daily weights of forage fed, refusal, and feces were used in the calculation of in vivo organic matter digestibility.

Diet samples were collected on 8 December in windrow pastures each year using 3 esophageally fistulated cows per pasture. Cows were held off feed overnight and allowed to graze 30 to 40 minutes for sample collections. Diet extrusa samples were collected in screenbottom bags.

All fecal and extrusa samples were stored frozen and then freeze-dried before chemical analyses. Samples were ground to pass through a $1-\mathrm{mm}$ screen in a Wiley mill. Diet extrusa samples were analyzed for dry matter and organic matter using standard methods (AOAC 1990). Nitrogen content was determined using a LECO CHN-1000 Elemental Analyzer ${ }^{2}$ and crude protein $(\mathrm{CP})$ expressed as $\mathrm{N} \times 6.25$. Neutral detergent fiber (NDF) was determined according to Van Soest et al. (1991), and acid detergent fiber (ADF) by

${ }^{1}$ Captec Chrome manufactured by Captec Pty. Ltd., Australia; distributed internationally by NuFarm Ltd., Manu Street, P.O. Box 22-407, Otahunu, Auckland 6, New Zealand. the method of Van Soest (1963). Fecal samples were analyzed for chromium concentration by atomic absorption spectrophotometry using an air plus acetylene flame (Williams et al. 1962).

\section{Forage Waste}

Forage waste under the windrow treatment was estimated from pre- and postgrazing weights of 2-m linear sections of windrow. Three, 2-m sections of windrow were located randomly in the area of each pasture that was initially grazed during December. Windrow sections were cut at the 2-m beginning and endpoints and slid onto a sheet of plywood. After weighing on a platform scale, the undisturbed windrow sections were placed back in their original locations. Sub-samples were collected for dry matter determination. Windrow section weights were taken on the day before the calves were allowed access to the area of pasture that contained a marked windrow section. Post-grazing weights of windrow sections were taken 30 days later using the same procedures as described for the pre-grazing weights. Weights of windrow sections before cow grazing were considered the same as the windrow weights after calf grazing. Weights of windrow sections after cow grazing were measured in February of each year.

To estimate forage waste by calves under the bale treatment, pre- and postfeeding weights of 3 bales per pen were taken. Post-feeding measurements took place 1 day after the round-bale feeder had been removed and a new bale was brought into a pen. New bales were placed at different locations within the pen. Hay that was refused and trampled in and around the round-bale feeder was collected and weighed. Sub-samples of both pre- and post-feeding hay were collected for dry matter determination.

\section{Effect of Time and Method of Storage on Forage Quality}

To evaluate the effect of time and method of storage on forage quality, samples of windrow, baled, and standing (stockpiled) forage were collected after hay harvest (September) and each month through February. Standing forage samples were collected from a $5 \times 30 \mathrm{~m}$ plot in each pasture that was not harvested for hay and excluded from any winter grazing. Standing forage was collected by hand-

\footnotetext{
${ }^{2}$ LECO Corporation, 3000 Lakeview Ave., St. Joseph, Mich. 49085-2396.
} 
clipping ten, 0.1- $\mathrm{m}^{2}$ randomly-located quadrats at each sample date. The standing forage was clipped to leave a 6 -cm stubble height. Windrows were sampled by handcollecting forage (approximately $50 \mathrm{~g}$ portions) at 10 random locations throughout each pasture. Samples were always collected from windrows that had not been grazed; including the February samples that were taken from a $40-\mathrm{m}$ length of windrow that had been specifically excluded from cow grazing. Bales were sampled using a $90-\mathrm{cm}$ hay-probe. At each date, a total of 10 sample cores were taken from at least 5 different bales that represented each pasture's bale production.

Composites were made for all forage sub-samples for treatment (standing, windrow, or bale) by replication by date groups. Samples were oven-dried at $60^{\circ} \mathrm{C}$ to a constant weight and ground to pass through a 1-mm screen. Samples were analyzed for dry matter, organic matter, $\mathrm{CP}, \mathrm{NDF}$, and ADF using the same procedures as described for the diet extrusa samples.

\section{Effect of Windrow Coverage on Subsequent Herbage Yield and Composition}

Each year following the winter grazing period by calves and cows, 3 plots where windrows had been located, were randomly selected in each pasture. These plots (4 by $4 \mathrm{~m}$ ), included the area covered by a 4-m length of windrow and the adjacent area not covered by a windrow (control). Fences were constructed to exclude grazing on these plots during the following spring. Sampling was conducted in midJuly of 1998 and 1999 by hand-clipping eight, $0.5 \mathrm{~m}^{2}$ quadrats in each plot. Four of the quadrats were in the windrow-covered area and 4 were in the adjacent control area. All herbage was clipped at ground level and sorted into grass, sedge/rush, legume, and forb components and then oven-dried at $60^{\circ} \mathrm{C}$ to a constant weight.

\section{Statistical Analysis}

Data were analyzed using analysis of variance procedures (SAS Institute Inc. 1985). Pastures were considered experimental units for analyses of the effect of time and method of storage on forage quality, hay yield, and effect of windrow coverage on subsequent vegetation production and composition. Windrow grazing pastures or bale-fed pens were experimental units for analyses pertaining to calf performance, forage intake, and forage waste. Model components include year, treatment, and replication. Year and treatment effects were tested using year $\mathrm{X}$ replication or treatment $\mathrm{X}$ replication as the error term. Year X treatment interaction effects were tested using the residual error term. Model components associated with the effect of time and method of storage on forage quality data included treatment, year, month, and replication. Treatment effects were tested using the treatment $X$ replication interaction as the error term. Year and year X treatment effects were tested using the pooled year $X$ replication and year $X$ treatment $X$ replication interactions as the error term. Month and all its interactions were tested using the residual error term. Treatment means of quality characteristics of standing, bale, and windrow stored forage were separated using Least Significant Difference (LSD) protected by a prior Ftest $(\mathrm{P}<0.05)$.

\section{Economic Analysis}

Partial budgeting techniques were used to compare the 2 strategies. Some costs common to both strategies were included to determine whether either strategy could be profitable over a range of calf prices. Fertilizer costs were included in both strategies and were based on the actual applications made to the study pastures as previously discussed. Other costs common to both strategies were the market value of the calves at the beginning of the trials and interest on that value. Interest was charged at a $10 \%$ nominal rate for the days calves grazed windrows or were fed hay. The calves were priced into each strategy based on November prices for western Nebraska and eastern Wyoming (personal communication, Livestock Marketing Information Center). The only other costs included were those that were different and associated with either windrow or bale strategies. For purposes of comparison, a 40.5 ha field, typical of ranch-scale operations, was assumed. Fencing costs for windrow included a two-wire electric fence around the perimeter of the field and a single-wire, portable fence used for allocating windrows to calves. We charged depreciation and interest on the average value of the fence investment (including energizer). We estimated it would require about 0.42 hours $\mathrm{ha}^{-1}$ of labor to erect the perimeter fence and move the internal fence to allocate windrows. Mowing, raking, baling and bale moving costs were based on custom rates for Nebraska (Jose and Miller 1998). The only difference in hay costs between the 2 strategies was the lack of baling and bale moving costs for windrow. Hay yields were assumed the same.

The bale strategy required estimation of bale feeding costs. A budget for hay feeding was developed based on feeding round bales to an equivalent number of calves (410) as would graze 40.5 ha of windrows. We assumed that a 6-bale processor pulled by a $78 \mathrm{~kW}$ tractor would be used to feed the calves. Depreciation and interest on average inves iment value for the tractor and bale pro'essor were charged as well as estimater. fuel, lubrication and repair costs. Ve assumed a 10 -year life with 0 salvage value for the bale processor, wl. $^{l}$ ich would be used to feed $1000 \mathrm{Mg}$ per year. We estimated that the tractor would be operated an average of 500 hours per year and would be traded after 7 years. Labor estimates for feeding hay were based on records kept by GSL staff for feeding cattle.

All costs including fertilizer and fuel, are for 1998, the mid-point of the research trials. Costs were calculated on a per hectare or per $\mathrm{Mg}$ basis depending on the feed source and then converted to a per head basis. The conversion was based on the intake estimates and feed records from the 2 years of the study.

Net returns from the retained ownership strategies were calculated by subtracting the costs described above from the gross revenue generated by multiplying appropriate feeder calf prices times the actual weights of cattle on the trials. Feeder calf prices for the average of January and February were used (personal communication, Livestock Marketing Information Center) since the calves finished trials near the end of January or early February. Note that the cost estimates do not include deductions for returns to land, management, or overhead. We assumed that those costs would be similar between strategies. We compared net returns for the 2 years of the study based on the livestock gains observed. We used 1998 costs but prices for $1997 / 1998$ and 1998/1999. The November prices for the first year of each trial period (1997 or 1998) were used to calculate calf cost as it entered the strategies. Values for calves at the end of the trials were estimated using January/February prices for the succeeding year (1998 or 1999).

A final comparison of net returns was made for the option of selling hay. Hay was priced at the field, based on the average of "all hay" and "other hay" prices for the years 1992-1999 (Nebraska Agricultural Statistics Service 1999, 2000). Fertilizer and harvesting costs, 
including bale moving, were used to estimate costs for the hay enterprise. Net returns from the hay enterprise were compared to net returns received from windrow and bale strategies using prices relevant for the years 1992-1999 and a projected gain of $0.23 \mathrm{~kg} \mathrm{day}^{-1}$. This series was chosen since prices have been reported by 50-pound increments since 1992 and this period covers a wide price range. Costs were held constant at 1998 levels since we were interested in price effects, which tend to be more variable than costs. Cattle gains were held constant at $0.23 \mathrm{~kg}$ day $^{-1}$ since 2 years of data are inadequate for assessing production variability and calves under both strategies attained that level of performance each year of the trial.

\section{Results and Discussion}

Annual precipitation during 1997 and 1998 was 87 and $96 \%$ of the mean, respectively. Precipitation during the September through January sampling period was 104 and $119 \%$ of the mean $(108 \mathrm{~mm})$ during 1997-98 and 1998-99, respectively (Fig. 1). Snowfall during the mid-November through January grazing and feeding period each year was relatively light with a maximum of $63 \mathrm{~mm}$ recorded during a single-day event. Snowfall events of 152 $\mathrm{mm}$ (October 1997) and $127 \mathrm{~mm}$ (November 1998) occurred before the start of the grazing and feeding periods. Melting of the majority of snow from all events occurred within 2 to 4 days.

\section{Hay Yield and Herbage Standing Crop}

Despite a 3-week later harvest date in 1998 compared to 1997, hay yield from the wet meadow pastures was similar over years $(\mathbf{P}>0.05)$ and averaged $4,460 \mathrm{~kg} \mathrm{ha}^{-1}$. Hay yield was $780 \mathrm{~kg} \mathrm{ha}^{-1}$ higher in fertilized plots compared to the control ( $\mathrm{P}<$ 0.10 ). Nichols et al. (1990), working on a similar wet meadow site, reported a hay yield of about $6,600 \mathrm{~kg} \mathrm{ha}^{-1}$ when similar rates of fertilizer were applied in April and the hay harvested in July. Hay yield was about $1,800 \mathrm{~kg} \mathrm{ha}^{-1}$ higher under fertilization compared to a control (Nichols et al. 1990). Although our observed hay yield was considerably less than that reported by Nichols et al. (1990), our management included grazing of the pastures in May (96 AUD ha ${ }^{-1}$ ). We applied fertilizer in early June after the grazing period. Because these pastures were dominated by cool-season species, it is likely that fertilizer-use efficiency and yield response could have been
Table 1. Body weights and gains of calves grazing windrows or fed baled, wet meadow hay.

\begin{tabular}{|c|c|c|c|c|}
\hline \multirow[b]{2}{*}{ Trial year } & \multirow[b]{2}{*}{ Item } & \multicolumn{2}{|c|}{ Treatment } & \multirow[b]{2}{*}{ SEM $^{1}$} \\
\hline & & Windrow grazing & Bale-fed & \\
\hline \multirow[t]{4}{*}{ 1997-98 } & Initial weight, $\mathrm{kg}$ & 204 & 203 & 1.90 \\
\hline & Final weight, kg & $241^{\mathrm{a}}$ & $230^{b}$ & 2.04 \\
\hline & Total gain, kg & $37^{\mathrm{a}}$ & $27^{\mathrm{b}}$ & 1.31 \\
\hline & Daily gain, kg day ${ }^{-1}$ & $0.53^{\mathrm{a}}$ & $0.39^{b}$ & 0.02 \\
\hline \multirow[t]{4}{*}{ 1998-99 } & Initial weight, $\mathrm{kg}$ & 201 & 204 & 1.80 \\
\hline & Final weight, kg & 220 & 221 & 1.51 \\
\hline & Total gain, kg & 19 & 17 & 1.44 \\
\hline & Daily gain, kg day ${ }^{-1}$ & 0.26 & 0.24 & 0.02 \\
\hline
\end{tabular}

Standard error of the mean, $\mathrm{N}=6$.

${ }^{\mathrm{a}}$ Within rows, treatment means with unlike superscripts differ $(\mathrm{P}<0.05)$. improved with an April application.

Herbage standing crop at the beginning of the windrow grazing period (midNovember) was greater $(\mathrm{P}<0.05)$ in 1997 $\left(1,400 \mathrm{~kg} \mathrm{ha}^{-1}\right.$ compared to 1998 (440 kg $\left.\mathrm{ha}^{-1}\right)$. These estimates included all growth that occurred after the 1 September 1997 or 22 September 1998 hay harvest as well as any residual plant material that was below the $6-\mathrm{cm}$ mowing height. The lower standing crop in 1998 was primarily attributed to the later cutting date and differences in fall growing conditions. The date of the first hard freeze $\left(\leq-4^{\circ} \mathrm{C}\right)$ occurred on 12 October 1998 compared to 25 October 1997. Herbage standing crop after the calf windrow grazing period (lateJanuary) also was greater during the first trial year (990 kg ha $\left.{ }^{-1}\right)$ compared to the second year $\left(400 \mathrm{~kg} \mathrm{ha}^{-1}, \mathrm{P}<0.05\right)$. This equates to 28 and $9 \%$ disappearance of the herbage standing crop during the calf windrow grazing period during the first and second trial years, respectively.

\section{Calf Weight Gain}

There was a year by treatment interaction effect for calf weight gain (Table 1). During the first year of the trial, windrow calves gained $37 \mathrm{~kg}$ compared to $27 \mathrm{~kg}$ for bale calves. There was no difference in weight gain between treatments during the second year of the trial.

The greater weight gain for windrow calves during 1997-98 was likely due to the presence of high quality regrowth that occurred after haying. Diet samples collected from esophageal-fistulated cows on 8 December 1997 contained $14.6 \% \mathrm{CP}$ compared to $10.4 \% \mathrm{CP}$ for hand-collected samples of windrows (Table 2). Acid detergent fiber and NDF content of diets, windrow, and baled hay samples were similar $(P>0.05)$. During the diet collection period, the cows were observed to consume windrow-stored forage, but also spent considerable time selecting green plant material that was present in the areas between windrows. Some of the regrowth

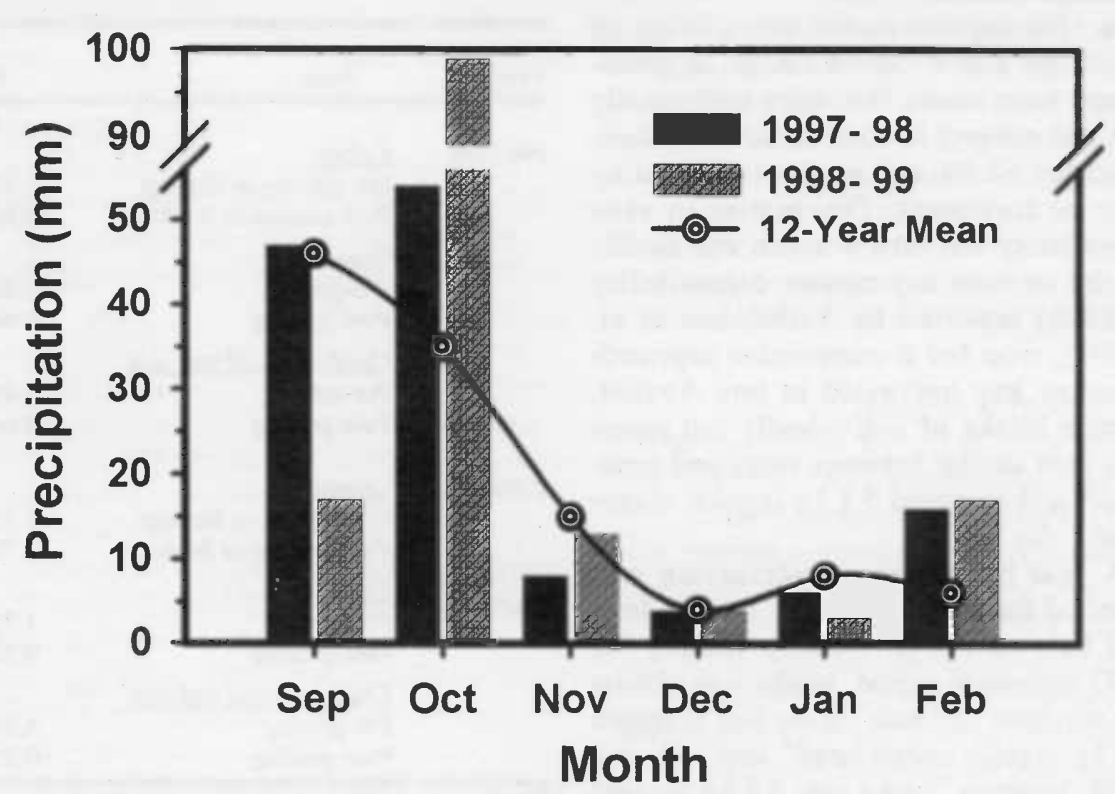

Fig. 1. Monthly and 12-year means of precipitation during the trial period at the Gudmundsen Sandhills Laboratory near Whitman, Nebr. 
Table 2. Percentage crude protein (CP), acid detergent fiber (ADF), and neutral detergent fiber (NDF) of diets from esophageal-fistulated cows in windrow grazing pastures, grab-samples hand-collected from windrows, and core samples collected from bales ${ }^{1}$.

\begin{tabular}{|c|c|c|c|c|}
\hline Year & Treatment & $\mathrm{CP}$ & $\mathrm{ADF}$ & NDF \\
\hline 1997 & $\begin{array}{l}\text { Diets in windrow grazing pastures } \\
\text { Windrow grab samples } \\
\text { Baled hay samples }\end{array}$ & $\begin{array}{l}14.6^{\mathrm{a}} \\
10.4^{\mathrm{b}} \\
10.3^{\mathrm{b}}\end{array}$ & $\begin{array}{l}(\%)- \\
40.9 \\
39.5 \\
40.3\end{array}$ & $\begin{array}{l}60.9 \\
62.2 \\
60.4\end{array}$ \\
\hline 1998 & $\begin{array}{l}\text { Diets in windrow grazing pastures } \\
\text { Windrow grab samples } \\
\text { Baled hay samples }\end{array}$ & $\begin{array}{l}12.1 \\
10.9 \\
10.5\end{array}$ & $\begin{array}{l}44.3 \\
42.0 \\
42.8\end{array}$ & $\begin{array}{l}63.7 \\
61.0 \\
61.2\end{array}$ \\
\hline
\end{tabular}

Organic matter basis. All samples were collected on 8 December each year.

${ }^{\mathrm{ab}}$ Within year and quality component, treatment means with unlike superscripts differ $(\mathrm{P}<0.05)$. in the windrow pastures was observed to remain green as late as 20 December 1997. Calf weights taken in early December and January showed daily gains under windrow grazing were greater than bale-fed during November and December. Daily gains during January were similar between windrow and bale groups.We found no studies in the literature that evaluated calf weight gain under windrow grazing and bale-feeding strategies. However, Turner and Angell (1987) reported that by the end of the winter, cows grazing rake-bunched meadow forage were $10 \mathrm{~kg}$ heavier than cows fed meadow hay. In a 3-year trial in Saskatchewan, cows grazing windrowed oats during November to January gained an average of $0.42 \mathrm{~kg} \mathrm{day}^{-1}$ while cows fed free-choice straw supplemented with oat silage and grain gained $0.28 \mathrm{~kg} \mathrm{day}^{-1}$ (AAFRD 1998).

\section{Forage Intake}

In vivo organic matter digestibility of baled hay and windrow forage, as determined from steers that were individually fed and subject to total fecal collection, averaged $67.3 \%$ and was not affected by year or treatment. Dry matter in vivo digestibility was $60.4 \%$ which was similar to the in vivo dry matter digestibility $(60.8 \%)$ reported by Villalobos et al. (1997), who fed a comparable regrowth meadow hay harvested in late August. Forage intake of individually fed steers was also similar between years and treatments and averaged $5.1 \mathrm{~kg}$ organic matter head $^{-1}$ day $^{-1}$.

A year by treatment interaction was detected for forage intake by the windrow and bale calves $(\mathrm{P}<0.05)$. During the 1997 collection period, intake was similar for windrow and bale calves and averaged $5.5 \mathrm{~kg}$ organic matter head ${ }^{-1}$ day $^{-1}$. During 1998 , however, intake was $5.5 \mathrm{~kg}$ organic matter head ${ }^{-1}$ day $^{-1}$ for windrow calves compared to $4.9 \mathrm{~kg}$ organic matter head ${ }^{-1}$ day $^{-1}$ for bale calves. The range of intake estimates given here corresponds to 2.3 to $2.6 \mathrm{~kg} / 100 \mathrm{~kg}$ body weight day $^{-1}$ for our calves. We expected intake of windrow calves to be higher in 1997 because of the greater weight gain (Table 1). From an analysis of steer gain and windrow and bale diets (NRC 1996), we postulated that windrow calf intake was likely over-estimated by the marker techniques in 1998 . The NRC (1996) analysis showed that degradable intake protein and energy would support greater daily gains but gains were limited by metabolizable protein.

\section{Forage Waste}

Pre-grazing weight of windrow-stored forage averaged $4.21 \mathrm{~kg}$ linear $\mathrm{m}^{-1}$ and pre-feeding weight of bales was $450 \mathrm{~kg}$ (Table 3). Under our grazing management, forage waste (refusal) by windrow calves averaged $29 \%$ and was higher than waste by bale calves $(12.5 \%)$. Allowing cows to graze in the windrow pastures after the calf grazing period resulted in an additional $23 \%$ utilization of the windrow forage during the first year of the trial and an additional $75 \%$ utilization during the second year. Forage waste after the combined calf and cow grazing periods averaged $18 \%$ and $4 \%$ during the first and second year of the trial, respectively. The difference between years was largely due to the cow stocking rates that were applied. A single herd (145 head) sequentially grazed each windrow pasture for 2 days ( 107 AUD $h^{-1}$ ) during the first year of the trial and for 3 days (161 AUD ha ${ }^{-1}$ ) during the second year.

Our estimate of round-bale feeding waste was higher than that reported by Smith et al. (1974), who estimated $4.7 \%$ waste by cows fed bales in rack feeders. Kallenbach (2000) reported 5.4\% waste when using round bales and feeders. When round bales were spread or unrolled across a feed-ground, Kallenbach (2000) reported waste ranging from 12.3 to $43.0 \%$, depending on the number of day's supply that was provided. There are also additional forage losses associated with round-bale packaging. Shrock and Fairbanks (1975) found that because of leaf shattering, greater forage loss occurred when using a round baler compared to a rectangular baler. Estimates of lost forage due to hay
Table 3. Mean pre- and post-grazing or feeding weights ( \pm standard error) (dry matter basis) of windrows and bales and forage waste by cattle grazing windrows or fed baled hay ${ }^{1}$.

\begin{tabular}{|c|c|c|c|c|c|}
\hline \multirow[b]{2}{*}{ Year } & \multirow[b]{2}{*}{ Item } & \multicolumn{2}{|c|}{ Windrows } & \multicolumn{2}{|c|}{ Bales } \\
\hline & & Weight & Waste & Weight & Waste \\
\hline \multirow[t]{9}{*}{ 1997-98 } & Calves & $--\left(\mathrm{kg} \mathrm{m}^{-1)}--\right.$ & $--(\%)--$ & $--(\mathrm{kg})--$ & $--(\%)--$ \\
\hline & Pre-grazing or feeding & $3.49 \pm 0.52$ & - & $446 \pm 2$ & - \\
\hline & Post-grazing or feeding & $0.88 \pm 0.38$ & $24^{\mathrm{a}}$ & $54 \pm 5$ & $12^{\mathrm{b}}$ \\
\hline & Cows & & & & \\
\hline & $\overline{\text { Pre-grazing }}$ & $0.88 \pm 0.38$ & - & $-{ }^{2}$ & - \\
\hline & Post-grazing & $0.64 \pm 0.23$ & 77 & - & - \\
\hline & Combined calf and cow & & & & \\
\hline & Pre-grazing & $3.49 \pm 0.52$ & - & - & - \\
\hline & Post-grazing & $0.64 \pm 0.23$ & 18 & - & - \\
\hline \multirow[t]{9}{*}{ 1998-99 } & Calves & & & & \\
\hline & Pre-grazing or feeding & $4.93 \pm 0.25$ & - & $452 \pm 6$ & - \\
\hline & Post-grazing or feeding & $1.79 \pm 0.80$ & $34^{\mathrm{a}}$ & $58 \pm 5$ & $13^{\mathrm{b}}$ \\
\hline & Cows & & & & \\
\hline & Pre-grazing & $1.79 \pm 0.80$ & - & - & - \\
\hline & Post-grazing & $0.22 \pm 0.06$ & 25 & - & - \\
\hline & Combined calf and cow & & & & \\
\hline & Pre-grazing & $4.93 \pm 0.25$ & - & - & - \\
\hline & Post-grazing & $0.22 \pm 0.06$ & 4 & - & - \\
\hline
\end{tabular}

Trial years were different with respect to forage waste by cows and the combined calf and cow waste $(\mathrm{P}<0.05)$

${ }^{2}$ Cows were not allowed to utilize baled hay remaining after calves.

${ }^{\mathrm{ab}} \mathrm{Bales}$ and windrows were different with respect to forage waste by calves $(\mathrm{P}<0.05)$. 

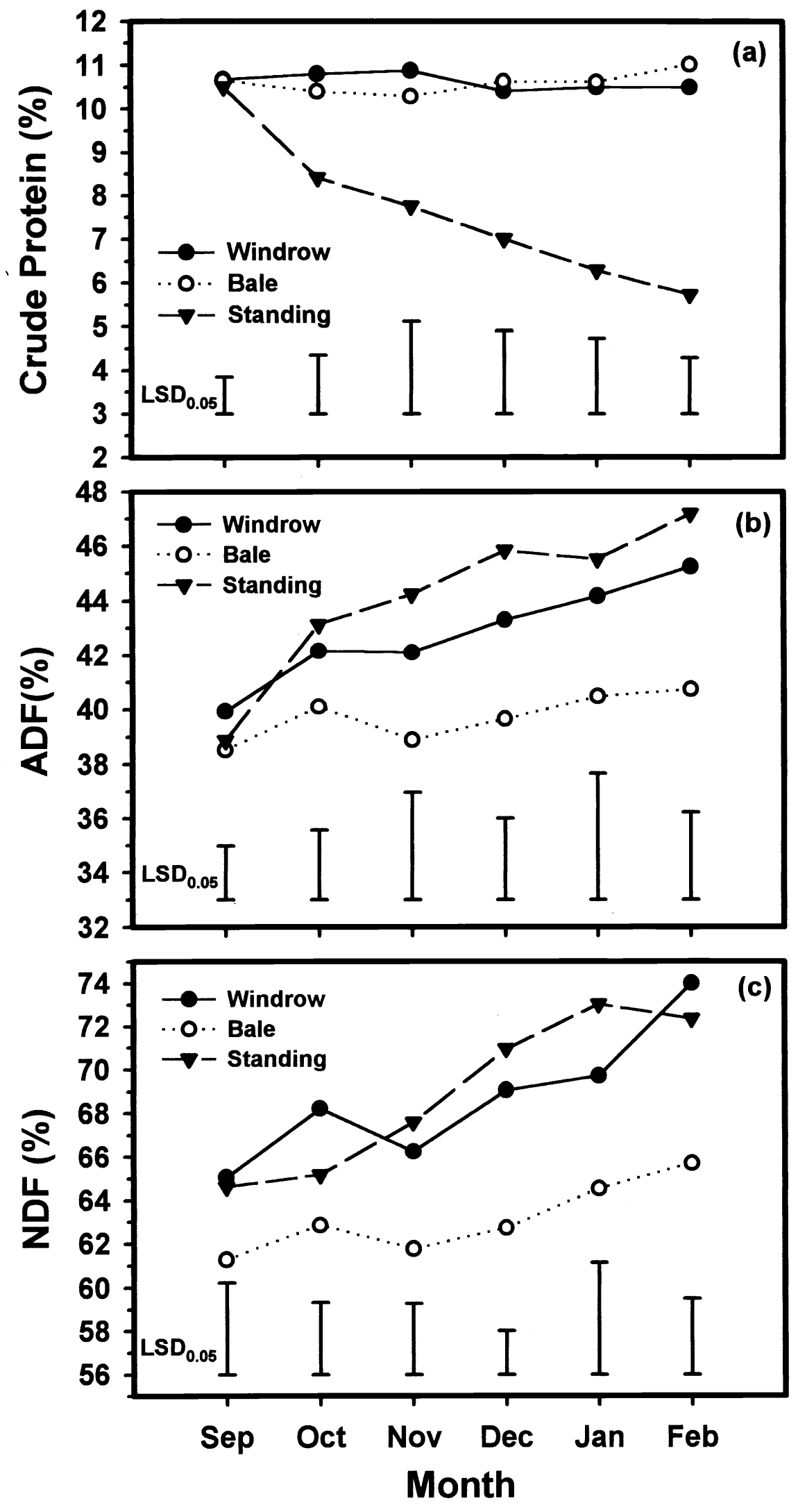

Fig. 2. Effect of time and method of storage on (a) crude protein, (b) acid detergent fiber (ADF), and (c) neutral detergent fiber (NDF) of wet meadow hay (organic matter basis), 1997-98 and 1998-99. not being picked up by the baler, shatter during the packaging process, and losses during transport average $8 \%$ (Anderson and Mader 1984).

\section{Effect of Time and Method of Storage on Forage Quality}

Year did not affect crude protein (CP) content, acid detergent fiber (ADF), or neutral detergent fiber (NDF) of windrow, baled, or standing (stockpiled) forage $(\mathrm{P}>$ 0.05). A treatment by month interaction was detected for $\mathrm{CP}$ content. Crude protein content under windrow, baled, and standing storage treatments was similar in September (10.6\%), but CP of standing forage declined to $5.7 \%$ by February (Fig. $2 a)$. Crude protein content of windrowand baled-stored forage was similar over all sampling months. Streeter et al. (1966), in a study using upland Sandhills hay (primarily warm-season), reported no differences in the winter crude protein content of hay that was either baled (small round), windrow-stored, or bunched in piles and stored. Crude protein content of forage that was left standing, however, declined by nearly $50 \%$ from summer to winter. Moxon et al. (1951) also reported higher CP content in windrow-stored forage compared to that left standing.

Acid detergent fiber (ADF) of windrow, bale, and standing forage was similar during September and averaged $39.1 \%$ (Fig $2 b)$. There was a treatment by month interaction effect on ADF $(\mathrm{P}<0.05)$. Acid detergent fiber of standing forage was greater than bale-stored forage from October through February. There was no difference in ADF between standing and windrow-stored forage during all sampling months. For these 2 treatments, ADF increased each month and averaged $46.2 \%$ in February. Neutral detergent fiber (NDF) was similar for windrow, bale, and standing forage treatments during September and averaged $63.6 \%$ (Fig. 2c). Similar to ADF, there was a treatment by month interaction effect on NDF, where NDF of standing and windrow-stored forage was higher than that of bale-stored forage from November through February. In February, NDF of standing and windrowstored forage averaged $73.1 \%$ compared to $65.7 \%$ for bale-stored forage.

Several factors likely contributed to the decline in quality of our standing forage. Plant maturity is considered the major factor affecting plant morphology and determining forage quality (Nelson and Moser 1994). The plants in our study pastures (primarily cool-season) continued growth and advanced in maturity until hard- 
freezes in October. After October, nutrient losses were probably due to leaching and leaf loss associated with weathering. Burzlaff and Clanton (1971) reported that in vitro dry matter digestibility (IVDMD) of upland Sandhills hay significantly declined with time when field-stored as bunches, windrows, or left standing. This is consistent with our results given the negative relationship between ADF and IVDMD (Van Soest 1987). Although they were not measured in our study, mineral and vitamin content as affected by storage method may be an important consideration. Streeter et al. (1966) reported little change in phosphorus content when storage treatments involved cutting the forage. Phosphorus in standing forage, however, declined significantly with time. Carotene, the vitamin A precursor, generally declines with time in all stored forages (Moser 1980), however, Streeter et al. (1966) found a slower decline under balestorage compared to windrows, bunches, or standing forage.

Although yield was considerably less compared to management that uses a July harvest date without any prior grazing (Nichols et al. 1990), our management practice of grazing the wet meadow pastures in May likely enhanced the quality of forage harvested in September (Table 2, Fig. 2a, 2b, 2c). A large portion of the plants appeared to be vegetative when harvested in September suggesting that stage of maturity was a primary factor contributing to quality. Villalobos et al. (1997) reported a crude protein content of $15.3 \%$ for hay that consisted of regrowth harvested in late August after an initial June harvest. For meadow that was not grazed during May, Nichols et al. (1990) reported a $\mathrm{CP}$ content of $8.3 \%$ for hay harvested in July. Reece et al. (1994), working on a wetland meadow site, reported CP contents of $8.3,6.0$, and $5.8 \%$ when harvest dates were 15 June, 15 July, and 15 August, respectively.

\section{Effect of Windrow Coverage on Subsequent Vegetation Production and Composition}

In July of the growing seasons following windrow grazing, composition of wet meadow herbage averaged $63 \%$ grasses, $30 \%$ sedges and rushes, $6 \%$ legumes, and $1 \%$ forbs. Total herbage yield was $20 \%$ less in the area directly covered by windrows compared to the control (Table 4). This difference was due to $1,280 \mathrm{~kg} \mathrm{ha}^{-1}$ less grass yield under the windrow covered treatment compared to the control. There were no treatment effects on yield of the sedge/rush, legume, and forb plant groups; although the treatment effect on forb yield was approaching statistical significance $(\mathrm{P}$ $=0.12$ ). Visual observations indicated that dandelion (Taraxacum officinale Weber) and common lambsquarters (Chenopodium album L.) were the most abundant forbs.

Table 4. Effect of windrow coverage on subsequent wet meadow herbage yield and composition, July, 1998 and 1999.

\begin{tabular}{|c|c|c|c|}
\hline Plant group & Treatment & Control & SEM $^{1}$ \\
\hline & $\cdots$ (kg ha & & \\
\hline Grasses & $2,900^{\mathrm{a}}$ & $4,180^{\mathrm{b}}$ & 466 \\
\hline Sedges / rushe & 2,020 & 1,990 & 434 \\
\hline Legumes & 370 & 350 & 102 \\
\hline Forbs & 230 & 90 & 53 \\
\hline Total & $5,520^{\mathrm{a}}$ & $6,610^{b}$ & 305 \\
\hline
\end{tabular}

${ }^{\mathrm{T}}$ Standard error of the mean, $\mathrm{N}=9$.

${ }^{\mathrm{ab}}$ Within plant group, treatments means with unlike superscripts differ $(\mathrm{P}<0.05)$.

Although our data indicate a $20 \%$ reduction in total herbage yield in the area covered by windrows, only about $9 \%$ of the total area of a pasture is affected by windrow-coverage when $1-\mathrm{m}$ wide windrows are created $11 \mathrm{~m}$ apart. Applying this percentage to our data shows that for the entire pasture, the net effect due to windrow coverage would be about $100 \mathrm{~kg} \mathrm{ha}^{-1}$ or $1.5 \%$ less yield.

It is likely that the coverage by windrows contributed to individual grass plant death or at least reduced vigor. Vegetation during the previous fall exhibited etiolated growth when covered by windrows. Dormancy of plants under

Table 5. Costs of forage production and grazing or feeding for windrow grazing and bale-fed strategies. ${ }^{1}$

\begin{tabular}{|c|c|c|}
\hline Item & Windrow grazing & Bale-fed \\
\hline Forage production & \multicolumn{2}{|c|}{$\cdots \cdots\left(\$ h^{-1)} \ldots \ldots\right.$} \\
\hline Fertilizer and application & 79.87 & 79.87 \\
\hline Mow and rake & 24.69 & 24.69 \\
\hline Bale (large round) & - & 47.68 \\
\hline Move bales & - & 15.14 \\
\hline Total & 104.56 & 167.38 \\
\hline \multicolumn{3}{|l|}{ Grazing or feeding $^{2}$} \\
\hline & $\ldots\left(\$ \mathrm{ha}^{-1)} \ldots\right.$ & - - $\left(\$ \mathrm{Mg}^{-1}\right) \ldots$ \\
\hline Hay cost & 104.56 & 37.36 \\
\hline Feeding cost & & \\
\hline Labor & - & 1.76 \\
\hline Bale feeder (depreciation, interest, repair) & - & 5.58 \\
\hline Tractor (depreciation, interest, repair, fuel) & - & 4.80 \\
\hline Fence & 8.69 & - \\
\hline Labor & 4.15 & - \\
\hline Total costs $\mathrm{ha}^{-1}$ or $\mathrm{Mg}^{-1}$ & $\$ 117.41 \mathrm{ha}^{-1}$ & $\$ 49.50 \mathrm{Mg}^{-1}$ \\
\hline Feed cost head ${ }^{-1}$ & $\$ 11.60$ & $\$ 21.24$ \\
\hline Feed cost head ${ }^{-1}$ day $^{-1}$ & $\$ 0.16$ & $\$ 0.30$ \\
\hline
\end{tabular}

Explanation of assumptions and cost derivations are provided in Material and Methods section.

${ }^{2}$ Costs for windrow grazing are dollars ha ${ }^{-1}$ and costs for the bale-fed strategy are dollars $\mathrm{Mg}^{-1}$. 
Table 6. Net returns per hectare under windrow grazing, bale-fed, and hay-sell strategies ${ }^{1}$.

\begin{tabular}{|c|c|c|c|}
\hline Year & Windrow grazing & Bale-fed & Hay-sell \\
\hline & $\ldots \ldots \ldots$ & $\left(\$ h a^{-1}\right)$ & $\ldots \ldots \ldots \ldots \ldots$ \\
\hline $1992-93$ & 335.85 & 243.32 & 69.87 \\
\hline 1993-94 & 128.48 & 32.88 & 93.17 \\
\hline 1994-95 & 177.03 & 82.34 & 108.25 \\
\hline $1995-96$ & -125.10 & -223.96 & 123.33 \\
\hline $1996-97$ & 506.74 & 417.14 & 152.12 \\
\hline $1997-98$ & 461.82 & 371.23 & 202.84 \\
\hline $1998-99$ & 573.58 & 484.20 & 94.54 \\
\hline Mean & 294.06 & 201.10 & 120.59 \\
\hline Standard deviation & 248.35 & 251.97 & 44.58 \\
\hline Coefficient of variation (\%) & 84 & 125 & 37 \\
\hline
\end{tabular}

Based on use or hay production from 40.5 ha fertilized wet meadow and a yield of $4.97 \mathrm{Mg}$ ha ${ }^{-1}$ (as-fed basis), 410 calves $(227 \mathrm{~kg})$, a projected calf gain of $0.23 \mathrm{~kg} \mathrm{day}^{-1}$ for both windrow grazing and bale-fed treatments, the average of the Nov.-Jan. and Nov.-Feb. calf sale prices each year, and a 72-day windrow grazing or bale feeding period. Hay prices were marketing year averages (1992-1999).

since animal gains were similar. These returns do not include costs for land, management, or overhead.

In an analysis that projected strategy net returns for the years 1992 through 1999 , gain from the windrow grazing averaged $\$ 29.04$ head $^{-1}$ compared to $\$ 19.86$ head $^{-1}$ for bale-fed. This analysis was based on 1998 costs and steer calf prices during the given years. Animal gains were held constant at $0.23 \mathrm{~kg} \mathrm{day}^{-1}$ so the year to year differences reflect only price changes. Net returns for bale-fed were more variable compared to the mean as reflected by the coefficient of variation of $125 \%$ compared to $84 \%$ for windrow grazing.

In another analysis, net returns were calculated on a ha- ${ }^{-1}$ basis for windrow grazing, bale-fed, and a third strategy, selling hay (Table 6). The per head costs for both windrow and bale-fed strategies were converted to the ha ${ }^{-1}$ basis by the carrying capacity of a 40.5 ha wet meadow. That area would produce enough windrow grazing or bales to maintain 410 steer calves at the weights reflected in our study. We added the third option of selling the baled hay at prices relevant for the same years. Hay prices are for prices received by Nebraska producers for the marketing year (1 June to 31 May). The mean net returns for windrow grazing exceeded the net returns for the other 2 options by about $\$ 93$ and \$174 ha ${ }^{-1}$ for bale-fed and selling hay, respectively. In the 1995-1996 years, both retained ownership strategies lost money, but the hay selling strategy showed positive net returns. In fact, in 3 of the 7 years, selling hay would have generated more net returns than the bale-fed strategy. Net returns from selling hay exceeded those from windrow grazing in only one year. The coefficient of variation for selling hay was the lowest of the 3 options reflecting lower variation in net

\section{Literature Cited}

Adams, D.C., R.E. Short, M.M. Borman, and M.D. McNeil. 1991. Estimation of fecal output with an intraruminal continuous release marker device. J. Range Manage. 44:204-207.

Adams, D.C., R.T. Clark, S.A. Coady, J.B. Lamb, and M.K. Nielsen. 1994. Extended grazing systems for improving economic returns from Nebraska sandhills cow/calf operations. J. Range Manage. 47:258-263.

AAFRD (Alberta Agriculture, Food and Rural Development). 1998. An introduction to swath grazing in western Canada. Agdex 420/56-1. Edmonton, Alberta.

Anderson, B. and T. Mader. 1984. Management to minimize hay waste. Univ. of Nebraska Coop. Ext. Neb-Guide G-84738.

returns from year to year. A producer that is highly risk averse may choose this option to avoid losses such as those that occurred in 1995-1996.

\section{Conclusions}

Windrow grazing of meadow forage was an effective and feasible management strategy for wintering calves. The calves readily adapted to the strategy, however, winter grazing period conditions were mild during the 2 years of the study. Quality of windrow-stored forage remained relatively constant through the fall and into the winter months and resulted in adequate calf gains. Forage waste or refusal under windrow grazing is closely associated with grazing management. Strip grazing techniques that balance the supply and demand for 1- or 2-day periods may be more effective, but increase labor requirements. Our management practice of having cows graze at the end of the calf grazing period was also effective in reducing waste and results in additional savings in feed costs. We found that windrow coverage of the perennial vegetation reduced total herbage yield the following growing season. However, for the entire pasture, the net effect of reduced yield because of windrow coverage was minimal. Costs for windrow grazing were substantially less than those associated with the bale-fed strategy. Correspondingly, net returns per head and hectare were greater for windrow grazing compared to the bale-fed strategy. Highly risk averse producers may still prefer selling hay rather than windrow grazing or feeding bales since net return variation was the least for that strategy.
AOAC. 1990. Official methods of analysis. $\left(14^{\text {th }}\right.$ ed.) Assoc. of Official Analytical Chemists. Arlington, Virg.

Burzlaff, D.F. and D.C. Clanton. 1971. The production of upland hay in the Sandhills of Nebraska. Nebr. Agr. Exp. Sta. Bull. SB-517.

D'Souza, G.E., E.W. Marshall, W.B. Bryan, and E.C. Prigge. 1990. Economics of extended grazing systems. Amer. J. Alternative Agr. 5:120-125.

Hollingsworth, K.J., D.C. Adams, T.J. Klopfenstein, J.B. Lamb, and G. Villalobos. 1995. Supplement and forage effects on fecal output estimates from an intra-ruminal marker device. J. Range Manage. 48:137-140.

Jose, H. D. and W. Miller. 1998. 1998 Nebraska farm custom rates-Part I. Univ. of NE Coop. Extension, EC98-823-A.

Kallenbach, R. 2000. Reducing losses when feeding hay to beef cattle. Univ. of Missouri Coop. Ext. Agr. Guide G-4570.

Kartchner, R.J. 1980. Effects of protein and energy supplementation of cows grazing native winter range forage on intake and digestibility. J. Anim. Sci. 51432-438.

Lodge, R.W. 1970. Complementary grazing systems for the Northern Great Plains. J. Range Manage. 23:268-271.

McCaughey, W.P. 1997. Winter swath grazing in Manitoba. p.39-50. In: Proc. Manitoba Agri-Forum '97. Winnipeg, Manitoba, Canada.

Moser, L.E. 1980. Quality of forage as affected by post-harvest storage and processing, $\mathrm{p}$. 227-259. In: Crop Quality, Storage, and Utilization. Amer. Soc. Agron. and Crop Sci. Soc. Amer., Madison, Wisc.

Moxon, A.L., G.F. Gastler, G.E. Staples, and R.M. Jordan. 1951. Grass hay at its best; as shown by chemical analyses and feeding value. S. Dak. Agr. Exp. Sta. Bull. 405. 
NRC. 1996. Nutrient requirements of beef cattle. $\left(7^{\text {th }}\right.$ ed.). Nat. Acad. Press. Washington, DC.

Nebraska Agricultural Statistics Service. 1999. 1997-1998 Nebraska Agricultural Statistics. Nebraska Dept. of Agr. Lincoln, Nebr.

Nebraska Agricultural Statistics Service. 2000. 1998-1999 Nebraska Agricultural Statistics. Nebraska Dept. of Agr. Lincoln, Nebr.

Nelson, C.J. and L.E. Moser. 1994. Plant factors affecting forage quality, p. 115-154. In: Forage Quality, Evaluation, and Utilization. Amer. Soc. Agron. and Crop Sci. Soc. of Amer., Madison, Wisc.

Nichols, J.T. and D.C. Clanton. 1987. Complementary forages with range, $\mathrm{p}$. 137-144. In: Proc. Grazing Livestock Nutrition Conference. Jackson, Wyo.

Nichols, J.T., P.E. Reece, G.W. Hergert, and L.E. Moser. 1990. Yield and quality response of subirrigated meadow vegetation to nitrogen, phosphorus and sulfur fertilizer. Agron. J. 82:47-52.

Ocumpaugh, W.R. and A.G. Matches. 1977. Autumn-winter yield and quality of tall fescue. Agron. J. 69:639-643.
Reece, P.E., J.T. Nichols, J.E. Brummer, R.K. Engel, and K.M. Eskridge. 1994. Harvest date and fertilizer effects on native and interseeded wetland meadows. J. Range Manage. 47:178-183.

SAS Institute Inc. 1985. SAS user's guide: statistics. (Version 5 ed.), SAS Institute Inc. Cary, N.C.

Schrock, M.D. and G.E. Fairbanks. 1975. A comparative study of harvesting efficiency for three types of packaging machinery on alfalfa. Paper MC-75-902. Mid-Central Region Meeting. ASAE, St. Joseph, Mich.

Smith, W.H., V.L. Lechtenberg, S.D. Parsons, and D.C. Petritz. 1974. Suggestions for the storage and feeding of big-package hay. Purdue Univ. Coop. Ext. ID-97. West Lafayette, Ind.

Streeter, C.L., D.F. Burzlaff, D.C. Clanton, and L.R. Rittenhouse. 1966. Effect of stage of maturity, method of storage, and storage time on nutritive value of Sandhills upland hay. J. Range Manage. 19:55-59.

Turner, H.A. and R.F. Angell. 1987. Systems for reducing dependency on harvested forage for wintering cows. Proc. Western Section, Amer. Soc. Anim. Sci. 38:197-200.
Van Soest, P.J. 1963. Use of detergents in analysis of fibrous feeds. II. A rapid method for the determination of fiber and lignin. J. AOAC. 46:829-835.

Van Soest, P.J. 1987. Nutritional ecology of the ruminant. Cornell Univ. Press, Ithica, N.Y.

Van Soest, P.J., J.B. Robertson, and B.A. Lewis. 1991. Methods for dietary fiber, neutral detergent fiber, and non-starch polysaccharides in relation to animal nutrition. J. Dairy Sci. 74:3583-3597.

Vallentine, J.F. 1990. Grazing management. Academic Press Inc., San Diego, Calif.

Villalobos, G., D.C. Adams, T.J. Klopfenstein, J.T. Nichols, and J.B. Lamb. 1997. Grass hay as a supplement for grazing cattle I. Animal performance. J. Range Manage. 50:351-356.

Williams, C.H., D.J. David, and O. Iismaa. 1962. The determination of chromic oxide in feces samples by atomic absorption spectrophotometry. J. Agr. Sci. (Camb.) 59:381-385. 